\title{
Musical Connections: A Descriptive Study of Community-Based Choirs Consisting of Persons with Dementia and their Caregivers
}

\author{
Zach Anderson and Debra Sheets, Ph.D., FAAN* \\ University of Victoria \\ zacharyanderson20@gmail.com
}

\begin{abstract}
This descriptive qualitative study explores the key characteristics, benefits, and lessons learned from community-based choirs consisting of persons with dementia $(\mathrm{PwD})$ and their caregivers based on reports from choir administrators and directors. Although there is growing interest in choirs for $\mathrm{PwD}$, there has been no synthesis of information on these choirs. Semi-structured interviews were conducted between December 2016 and February 2017 with six administrators and/or directors of community-based choirs for $\mathrm{PwD}$ and their caregivers. The interviews were audio-recorded and transcribed. Content analyses indicated that choirs had many similarities in membership (e.g., early to mid-stage dementia), establishing formal sections and harmonies (e.g., soprano, alto, tenor, bass), administration (e.g., leadership, fees), and music programming (e.g., public performance, duration, and length of practice sessions). Benefits of the choir include enjoyment, sense of purpose, empowerment, caregiver support and respite, and increased awareness of dementia by others. In conclusion, this descriptive study suggests that community-based choirs are a cost effective and valuable program that improve quality of life for $\mathrm{PwD}$ and caregivers.
\end{abstract}

Keywords: social inclusion; dementia; family caregivers; community choir; intergenerational

$\mathrm{T}$ he term dementia is used to classify a group of neurocognitive disorders that worsen over time and affect memory, judgement, and behaviour (Alzheimer Society of Canada [ASC], 2017). Current dementia statistics in Canada estimate 564,000 Canadians are affected by the disorder, a number that by 2031 is projected to grow to 937,000 Canadians (ASC, 2016). Dementia has physical, psychological, social, and economic impacts on both the persons with dementia (PwD) and their caregivers and a significant financial impact on the health care system (ASC, 2015; Dassel \& Carr, 2016; Dugeon, 2010). There is no cure for dementia; however, there are pharmacological and non-pharmacological interventions that can improve quality of life through symptom management (ASC, 2015). Non-pharmacological interventions (e.g., music therapy) and staying active can maximize function and independence, reduce behavioural symptoms, reduce caregiver burden, and improve the quality of life for both $\mathrm{PwD}$ and caregivers (ASC, 2012; Dayanim, 2009; Hulme, Wright, Crocker, Olubovede, \& House, 2010; Maratos, Gold, Wang, \& Crawford, 2008; Sampath, Forbes, Barton, \& Blake, 2015; Wall \& Duffy, 2010).

Choral singing is a non-pharmacological intervention that is garnering increased interest due to promising findings from several pilot studies (Bannan \& Montgomery-Smith, 2008; Camic, Williams, \& Meeten, 2013; Unadkat, Camic, \& Vella-Burrows, 2016). Community-based choirs offer PwD and their caregivers an opportunity to engage in meaningful activity that promotes social engagement, physical activity (e.g., respiratory, musculoskeletal), and sensory stimulation (e.g., hearing, vision)

${ }^{*}$ This research was supported by the Jamie Cassels Undergraduate Research Award, University of Victoria. 
(Bannan \& Montgomery-Smith, 2008; Camic et al., 2013; H. Kivnick, personal communication, March 1, 2016; Unadkat et al., 2016). Some community-based choirs also include other participants such as students, which is beneficial for both students and $\mathrm{PwD}$ (Alzheimer Society London and Middlesex, 2017; Alzheimer Society Oxford, 2017; Alzheimer Society Waterloo Wellington, 2016; Harris \& Caporella, 2014) because PwD can develop new relationships and students can gain a better understanding of the lived experience of PwD (Harris \& Caporella, 2014).

The purpose of this study is to describe the organizational structures and identify common elements to the success of existing community-based choirs consisting of $\mathrm{PwD}$ and their caregivers based on reports from choir administrators and directors. While interest in choirs for PwD is growing, to our knowledge there has been no effort to systematically compare and contrast these choirs. It is timely and important to examine the perceived benefits as well as lessons learned from community-based choirs for PwD and their caregivers. The key research questions we asked were 1) What are the key characteristics of the choirs (e.g., program structures, sources of support/funding)? 2) What are the perceived benefits to participants? and 3) What are the lessons learned from existing choir programs (e.g., what works well and what does not)?

\section{Methods}

\section{Sample}

The purposive sample consisted of six community-based choirs for PwD and their caregivers (See Table 1). Choirs were identified using an internet search. Inclusion criteria for choirs selected were 1) choir performs publicly; 2) membership is primarily $\mathrm{PwD}$ and caregivers; 3) choir is community-based (i.e., participants are living at home); 4) choir leadership is English speaking; and 5) director is a music professional. Exclusion criteria were community singing groups in which there was 1) a primary focus on music therapy; or 2) a sing-along-group rather than a performing choir.

\section{Data Collection}

Semi-structured phone interviews lasting 30-45 minutes were conducted with key informants (e.g., director, administrator) of the choirs between December 2016 and February 2017. The interview guide was designed to elicit information on the choir administration, program structure, benefits to participants, and challenges. Interviews were audio-recorded and transcribed. Ethics approval was received from the University of Victoria and participants provided written informed consent.

\section{Analysis}

Interviews were transcribed and then independently reviewed by the authors to identify themes using the constant comparative method associated with grounded theory (Strauss \& Corbin, 1990). The authors then met to discuss the preliminary codes and identify themes. Disputes were resolved by discussion and joint review of transcripts. Descriptive analyses were summarized in tables. Quotations that the authors judged to be representative of the responses for each theme were selected for inclusion in this paper. 
Table 1

Overview of Choirs, their Locations, and Size

\begin{tabular}{|c|c|c|c|c|c|}
\hline Name $(n=6)^{*}$ & Location(s) & $\begin{array}{l}\text { Year prog- } \\
\text { ram started }\end{array}$ & $\begin{array}{l}\text { Choir size } \\
\text { when created }\end{array}$ & $\begin{array}{l}\text { Current } \\
\text { size }\end{array}$ & $\mathrm{PwD}^{* *}$ \\
\hline $\begin{array}{l}\text { Circle of Music } \\
\text { Intergenerational } \\
\text { Choir }\end{array}$ & Waterloo, ON (Canada) & 2016 & 30 & $\mathrm{n} / \mathrm{a}$ & 10 \\
\hline $\begin{array}{l}\text { Intergenerational } \\
\text { Singers } * * *\end{array}$ & Oxford, ON (Canada) & 2013 & 23 & $\begin{array}{l}n=23 \\
1 \text { choir }\end{array}$ & $3^{* * * *}$ \\
\hline $\begin{array}{l}\text { The Alchemy } \\
\text { Chorus }\end{array}$ & Canberra (Australia) & 2016 & 50 & $\begin{array}{l}n=80 \\
1 \text { choir }\end{array}$ & 30 \\
\hline $\begin{array}{l}\text { Sing Here Now } \\
\text { Choir }\end{array}$ & $\begin{array}{l}\text { Portland/Beaverton, } \\
\text { OR (USA) }\end{array}$ & 2011 & 20 & $\begin{array}{l}n=36 \\
2 \text { choirs }\end{array}$ & 18 \\
\hline $\begin{array}{l}\text { Giving Voice } \\
\text { Chorus }\end{array}$ & $\begin{array}{l}\text { Minneapolis/St. Paul, } \\
\text { MN (USA) }\end{array}$ & 2014 & 30 & $\begin{array}{l}n=174 \\
3 \text { choirs }\end{array}$ & $\sim 74$ \\
\hline $\begin{array}{l}\text { Forget-Me-Not } \\
\text { Chorus }\end{array}$ & $\begin{array}{l}\text { Cardiff/Newport, South } \\
\text { Wales (UK) }\end{array}$ & 2011 & 40 & $\begin{array}{l}n=125 \\
3 \text { choirs }\end{array}$ & $\sim 62$ \\
\hline
\end{tabular}

* " $n=x "$ denotes sample size.

** Ratio of caregiver to PwD is $1: 1$.

*** Includes high school or elementary school students.

**** This accounts for PwD from the community and does not include PwD participants from the retirement home.

\section{Results}

\section{Key Characteristics of Choirs}

Choir format and practice locations. A descriptive summary of choir format and practice locations is provided in Table 2 (see below). The duration of choir practice ranged from 60 minutes to 120 minutes. The singing portion lasted 40 minutes to 100 minutes. A short social time often preceded choir practice as people arrived and a longer social time during a midway break in practice or at the end, which generally included refreshments and allowed caregivers to connect with other caregivers while also providing a supportive and safe place for $\mathrm{PwD}$. Choir programs ranged from 16 to 40 weeks in length and were divided into seasons that lasted 8 to 30 weeks. Most $(n=5)$ choirs had multiple seasons in a year. Many $(n=4)$ choir practices were held in a donated room at a local organization.

Choir sections, volunteers, fees, and funding. A summary of choir sections, volunteers, fees, and funding is provided in Table 3 (see below). Some $(n=2)$ of the choirs only sang in unison while others $(n=4)$ incorporated sections with two-part melodies, harmonies and/or bass, alto, tenor, and soprano. Each choir utilized volunteers. Those that volunteered were church members, previous choir members, members of other choirs, and community members. Many $(n=3)$ of the volunteers were given training in regards to interacting and supporting PwD. Choir membership fees were implemented by some $(n=2)$ choirs. The majority of choirs relied on donations from private donors and/or charitable foundations to help fund their choir programs. 
Table 2

Summary of Community-Based Choir Format and Practice Location

\begin{tabular}{|c|c|c|c|c|c|}
\hline Name & $\begin{array}{l}\text { Singing } \\
\text { practice }\end{array}$ & $\begin{array}{l}\text { Structured } \\
\text { social time }\end{array}$ & $\begin{array}{l}\text { Weeks / } \\
\text { year }\end{array}$ & Practice location(s) & $\begin{array}{l}\text { Location } \\
\text { fees }\end{array}$ \\
\hline $\begin{array}{l}\text { Circle of Music } \\
\text { Intergenerational } \\
\text { Choir }\end{array}$ & 40 min. & 40 min. & 30 & Church & Donated \\
\hline $\begin{array}{l}\text { Intergenerational } \\
\text { Singers }\end{array}$ & $60 \mathrm{~min}$. & 0 min. & 16 & Retirement home & Donated \\
\hline $\begin{array}{l}\text { The Alchemy } \\
\text { Chorus }\end{array}$ & $90 \mathrm{~min}$. & 30-40 min. & 40 & Community centre & Rented \\
\hline $\begin{array}{l}\text { Sing Here Now } \\
\text { Choir }\end{array}$ & 75 min. & $25 \min$. & 16 & $\begin{array}{l}\text { Alzheimer Association } \\
\text { Office; Church }\end{array}$ & Donated \\
\hline $\begin{array}{l}\text { Giving Voice } \\
\text { Chorus }\end{array}$ & $90 \mathrm{~min}$. & $30 \mathrm{~min}$. & 40 & $\begin{array}{l}\text { Community centre; } \\
\text { Music school }\end{array}$ & Donated \\
\hline $\begin{array}{l}\text { Forget-Me-Not } \\
\text { Chorus }\end{array}$ & $100 \mathrm{~min}$. & 15 min. & 36 & $\begin{array}{l}\text { Community centre; } \\
\text { Church; School }\end{array}$ & Rented \\
\hline
\end{tabular}

Public performance. All $(n=6)$ choirs held at least one public performance per choir season. Many $(n=4)$ of the choirs hold their concerts in a donated space, while others $(n=2)$ perform in a rented space. One choir rents performance space because it requires a venue that can accommodate public attendance of 300-600 people. To cover the expense of renting a venue, tickets are sold to attend the concert. Another choir rents public performance spaces that are well known in the community as it gives the choir members a sense of pride to present their work there and raises the visibility of dementia within the community. To help cover some of the rental costs, there is a donation bucket at performances. In addition, several choirs $(\mathrm{n}=4)$ have been invited to perform by different groups and organizations.

Choir administration. One-half $(n=3)$ of the choirs rely on volunteer choir administrators, choir directors, and accompanists. Another $(n=1)$ choir has a paid program administrator with a volunteer choir director and accompanist. Some $(n=2)$ administrators give the volunteer choir directors and accompanists a small stipend or gifts of appreciation. The larger programs $(n=2)$ have a volunteer board of directors and paid administrators, music directors, and accompanists.

Time of practice. Most practice sessions $(n=5)$ are scheduled during daylight hours to make transportation and participation easier (i.e., less traffic, more parking, less fatigue, improved cognition). The intergenerational choirs $(n=2)$ schedule practice in the late afternoon to make it possible for students to participate. One choir has practice in the early evening, which makes it easier for family members to participate after work. No negative effects were reported by the choir that meets in the evening.

Recruitment. All the programs $(n=6)$ collaborated with an Alzheimer organization to advertise the program and/or recruit participants. Several programs $(n=4)$ advertised more broadly through newspaper, social media, radio, community centers, adult day programs, and word of mouth.

Choir requirements. Choir programs had varying requirements for participation. Some programs $(n=3)$ had broad requirements such as having a diagnosis of dementia where others $(n=3)$ required a specific stage of early to moderate dementia to participate. One choir administrator reported that there is a natural attrition in the choir as dementia progresses and functional abilities decline. A couple of programs $(n=2)$ stated that there are some participants with late stage 
dementia who still participate in the choir.

Sustainability. When asked about choir sustainability, all choir administrators $(n=6)$ reported that the choir programs are sustainable. Some noted that sustainability is based on ongoing volunteer support $(n=1)$ and ongoing fundraising $(n=2)$. Several $(n=3)$ choirs administrators plan to add additional groups in their area or expand to new areas. In order to appeal to different funding organizations, one choir administrator adjusts the focus of each choir season to receive further funding (e.g., adding an element of writing and poetry to the program).

Table 3

Overview of Choir Structure

\begin{tabular}{|c|c|c|c|c|c|}
\hline Name & $\begin{array}{l}\text { Choir } \\
\text { sections }\end{array}$ & Volunteers & $\begin{array}{l}\text { Volunteer } \\
\text { training }\end{array}$ & $\begin{array}{l}\text { Choir } \\
\text { member- } \\
\text { ship fees }\end{array}$ & Funding \\
\hline $\begin{array}{l}\text { Circle of Music } \\
\text { Intergenerational } \\
\text { Choir }\end{array}$ & Unison & Church members & Yes* & None & None \\
\hline $\begin{array}{l}\text { Intergenerational } \\
\text { Singers }\end{array}$ & $\begin{array}{l}\text { Sections/ } \\
\text { Unison }\end{array}$ & $\begin{array}{l}\text { Support } \\
\text { volunteers }\end{array}$ & Yes* & None & $\begin{array}{l}\text { Alzheimer Society } \\
\text { and donations at } \\
\text { concerts } * * *\end{array}$ \\
\hline $\begin{array}{l}\text { The Alchemy } \\
\text { Chorus }\end{array}$ & Unison & $\begin{array}{l}\text { Support/ singing } \\
\text { volunteers from } \\
\text { other choirs }\end{array}$ & $\mathrm{n} / \mathrm{a}$ & $\begin{array}{l}\$ 5 / \text { person/ } \\
\text { week }\end{array}$ & None \\
\hline $\begin{array}{l}\text { Sing Here Now } \\
\text { Choir }\end{array}$ & Sections & $\begin{array}{l}\text { Support } \\
\text { volunteers }\end{array}$ & $\mathrm{n} / \mathrm{a}$ & None & $\begin{array}{l}\text { Alzheimer } \\
\text { Association fund } \\
\text { raising }\end{array}$ \\
\hline $\begin{array}{l}\text { Giving Voice } \\
\text { Chorus }\end{array}$ & $\begin{array}{l}\text { Sections/ } \\
\text { Unison }\end{array}$ & $\begin{array}{l}\text { Support/ singing } \\
\text { volunteers }\end{array}$ & Yes & $\begin{array}{l}\$ 50 / \\
\text { person/ } 16 \\
\text { weeks }\end{array}$ & $\begin{array}{l}\text { Community } \\
\text { charity } \\
\text { foundations and } \\
\text { private donors }\end{array}$ \\
\hline $\begin{array}{l}\text { Forget-Me-Not } \\
\text { Chorus }\end{array}$ & Sections & $\begin{array}{l}\text { Support } \\
\text { volunteers }\end{array}$ & No** & None & $\begin{array}{l}\text { Forget-Me-Not } \\
\text { Chorus } \\
\text { Foundation: } \\
\text { community } \\
\text { charity } \\
\text { foundations and } \\
\text { private donors }\end{array}$ \\
\hline
\end{tabular}

* Training given to students participating in the choir as well.

** Volunteers are caregivers/previous choir members whose loved ones with dementia passed away.

*** These funds cover the $\$ 380$ annual cost of running the choir program.

\section{Benefits to Participants}

Purpose. Choir directors report the $\mathrm{PwD}$ and caregivers find the choir a significant source of meaning and purpose, as well as being relaxing and fun. 
- "The choir changed their lives. It's what they get up for. It gives them something to work on. Something was expected of them and they could do it."

- "One care partner says that his wife talks about the program all week long when it is in session because it is the thing she looks forward to during the week."

- "One caregiver said when things are really tough at home with my partner (with dementia), I just think about next Thursday and coming to choir and that helps me get through."

Empowerment. The choir offered opportunities to learn, to engage, and to communicate with others.

- "One of the men that takes part in the choir can really not make himself understood with words because of his aphasia and he can sing. He can sing beautifully. It gives him an opportunity to contribute, be successful, and be good at something."

- "Once someone gets diagnosed society writes them off as 'This person isn't going to be able to think anymore or be part of things anymore.' Through singing they can be part of things, they can learn, they can be engaged."

Enjoyment. The choir provides a supportive setting that allows participants to interact with others and have fun together.

- "One caregiver said that she doesn't remember the last time her husband smiled before he came to the choir and started singing."

- "They celebrate something they are still able to do. They are happy to be engaged and happy to interact with people that know what they are going through."

Caregiver support. Social networks have expanded and information is shared informally between caregivers.

- "When the care partners are talking to each other, they are likely to give referrals or insights into other resources in the community that they are using (i.e., in-home help, assisted living, transportation services). It means a lot more to the people when they talk to someone that has had personal experience with it."

- "You can have an hour and a half of not having that weight on your mind."

Discovery. For students and volunteers who participate, there is valuable learning that occurs and relationships that can develop where there might not have been the opportunity before.

- "A student from the high school latched onto the atmosphere provided by the choir and is still with us ... she has found a place to belong."

- "The principal of the elementary school said at the end of a session, 'I could not think of a better way to spend a Tuesday afternoon in the whole world." "

- "Students [gain] an understanding of dementia and develop empathy [by] conversation and getting some viewpoints from people you would not otherwise know."

Other reported benefits included improved behaviour after choir sessions, reduced isolation, feeling accepted, decreased depression, and increased confidence. 


\section{Lessons Learned}

Administrators of the community-based choirs were eager to share lessons learned and some of the challenges they had encountered. Lessons learned included the importance of structured social time and of participant recognition.

Structured social time. Many $(n=4)$ of the choirs emphasized the importance of a planned break time/social time that provides valuable time for peer support and relationships to develop. The social time also offers an opportunity for the caregiver to relax and interact with others since volunteers and other caregivers help to ensure a safe and supportive environment for the PwD.

Participant recognition. Some $(n=2)$ choir directors spoke of strategies that were successful in giving $\mathrm{PwD}$ a voice and empowering them further than just singing in the choir. The music director of one choir uses spotlighting-asking choir members' opinions and inviting members to do solos or lead part of the warm up. This choir also incorporates other forms of art such as poetry and visual displays at public performances that showcase the life and experiences of PwD. Another choir allows choir members to request songs that are significant to them. Before performing the song at a concert, the choir member that suggested the song shares the significance of that song (e.g., a childhood song or a song from their first date). The choir activities allow the PwD to develop a self-identity as a singer, contribute to a bigger group, and build their confidence in their ability to learn despite memory losses.

\section{Challenges}

Common challenges of establishing and maintaining a choir for PwD and their caregivers included 1) keeping sessions engaging; 2) selecting music that works well for the group (i.e., challenging yet familiar or simple and energetic); 3) having a large enough song repertoire; 4) working within a limited budget; 5) dealing with dementia progression; 6) and distance and transportation.

\section{Discussion}

This descriptive pilot study adds to a small but growing body of research literature on communitybased choirs for PwD (Bannan \& Montgomery-Smith, 2008; Camic, Williams, \& Meeten, 2013; Harris \& Caporella, 2014; Unadkat, Camic, \& Vella-Burrows, 2016). Our interviews identified many similarities in membership (e.g., early to mid-stage dementia), establishing formal sections and harmonies (e.g., soprano, alto, tenor, or bass), administration (e.g., leadership, fees), and music programming (e.g., public performance, practice sessions).

Choir directors and administrators report that the programs they are currently implementing have a positive impact on all participants. The $\mathrm{PwD}$ find enjoyment in participation, mental and social engagment, and a sense of purpose. These findings fit well with the literature (Bannan \& Montgomery-Smith, 2008; Camic et al., 2013; Unadkat et al., 2016). The benefits that caregivers experience such as social support and enjoyment also fit well with what has been found previously in the literature (Camic et al., 2013; Unadkat et al., 2016). A planned social time can play an important part in providing the opportunity for peer support. This support can be crucial in alleviating the social isolation and stress that often occurs among caregivers of PwD. Students that particpated also benefited through interacting with $\mathrm{PwD}$, as the literature suggested (Harris \& Caporella, 2014).

A similar non-pharmacological intervention to a community-based choir is music therapy. Music therapy can consist of listening to music, creating music, dancing, and singing (American Music Therapy Association, 2017). Music therapy has shown to be effective in reducing disruptive behaviours, anxiety, and depressive moods, and when done in groups can promote social engagement (Ahn \& Ashida, 2012; Chang et al., 2015; Matthews, 2015). The literature also shares that music 
therapy is a low-cost intervention that has positive benefits (Ahn \& Ashida, 2012; Chang et al., 2015; Matthews, 2015). A community-based choir shares similar aspects and benefits as music therapy; however, a community-based choir adds the unique aspect of public performance. Performing and sharing talents can bring a sense of empowerment and new levels of engagement that music therapy might not provide for $\mathrm{PwD}$ and caregivers. Public performance also raises the visibility of dementia, can change perceptions, and can reduce stigma. These opportunities might not be possible with music therapy.

The unique aspect of public performance in community-based choir participation might not appeal to all $\mathrm{PwD}$ and their caregivers. One choir director mentioned the reluctance of $\mathrm{PwD}$ to participate in the choir if they had no prior experience singing in a choir. Community-based choirs may be an effective intervention for a specific group of $\mathrm{PwD}$ that enjoy singing in public and having weekly social engagement. As observed by the increasing number of participants in the community-based choirs in this study, there is a growing interest.

With volunteer support and donated space for practices and performances, forming and maintaining a community-based choir can be successful with an annual expense as low as $\$ 380$. As a choir grows and requires a larger space to practice and larger venues to perform, the expenses go up. A choir may need to charge participation fees or look to outside funding to support the program.

\section{Limitations}

This descriptive study is exploratory and has several limitations. The sample size is small and purposive with no comparison group, which decreases generalizability. In addition, constraints on time and resources prevented additional interviews, so this study does not reflect the entire population of community-based choirs for $\mathrm{PwD}$ and caregivers and only reflects perspectives of western cultures. The study also does not gather primary data from participants, so findings reflect the perceptions of the key informants, which may introduce bias.

\section{Conclusion}

A community-based choir offers PwD and caregivers an opportunity to share an enjoyable activity in a supportive setting. The community setting brings $\mathrm{PwD}$ and caregivers out of isolation and into a network of support and engagement. PwD regain an identity in which they can continue to learn, express themselves, and be part of a socially meaningful activity. A community-based choir also benefits people other than the $\mathrm{PwD}$ and caregivers. The low cost of establishing a community-based choir for $\mathrm{PwD}$ and their caregivers make these programs an attractive approach for a non-pharmacological intervention. Since the conception of several of the community-choirs, there has been substantial growth in membership, showing interest in the dementia community; however, because these programs are relatively new, long-term stability and the impact on outcomes has yet to be studied. A community-based choir for $\mathrm{PwD}$ and caregivers has the potential to positively impact $\mathrm{PwD}$, caregivers, and a whole community. Suggestions for future research include using a randomized control trial that will gather data directly from $\mathrm{PwD}$ and caregivers in comparing the impact and benefits of the choir versus other interventions (e.g., exercise); developing a formal evaluation tool to identify what is needed to ensure program quality; and determining which non-pharmacological intervention related activities are of most interest to $\mathrm{PwD}$ and caregivers in order to provide programs that are individualized to personal interests and encourage participation. 


\section{References}

Ahn, S., \& Ashida, S. (2012). Music therapy for dementia. Maturitas, 71(1), 6-7. doi:10.1016/j.maturitas.2011.10.013

Alzheimer Society of Canada (2012). Benefits of staying active. Retrieved from http://www.alzheimer .ca/en/Living-with-dementia/Day-to-day-living/Staying-active/Benefits-of-staying-active

Alzheimer Society of Canada (2015). Treatment options. Retrieved from http://www.alzheimer.ca/en /About-dementia/Treatment-options

Alzheimer Society of Canada (2016). Prevalence and monetary costs of dementia in Canada. Toronto, ON: Alzheimer Society of Canada

Alzheimer Society of Canada (2017). What is dementia? Retrieved from http://www.alzheimer.ca/en/ About-dementia/What-is-dementia

Alzheimer Society London and Middlesex (2017). Social recreation programs. Retrieved from http://www.alzheimerlondon.ca/we-can-help/program-and-services/social-recreation-programs

Alzheimer Society Oxford (2017). The intergenerational singers. Retrieved from http://www.alzheimer. ca/en/oxford/News-and-Events/Events/The-Intergenerational-Singers

Alzheimer Society Waterloo Wellington (2016). Intergenerational choir - circle of music. Retrieved from http://www.alzheimer.ca/en/ww/We-can-help/Programs/Intergenerational\%20Choir\%20\%20Circle\%20of\%20Music

American Music Therapy Association (2017). What is music therapy? Retrieved from https://www. musictherapy.org/about/musictherapy/

Bannan, N., \& Montgomery-Smith, C. (2008). Singing for the brain: Reflections on the human capacity for music arising from a pilot study of group singing with Alzheimer's patients. The Journal of the Royal Society for the Promotion of Health, 128(2), 73-78. doi: $10.1177 / 1466424007087807$

Camic, P. M., Williams, C. M., \& Meeten, F. (2013). Does a 'Singing together group' improve the quality of life of people with a dementia and their carers? A pilot evaluation study. Dementia, 12(2), 157-176. doi:10.1177/1471301211422761

Chang, Y., Chu, H., Yang, C., Tsai, J., Chung, M., Liao, Y., ... Chou, K. (2015). The efficacy of music therapy for people with dementia: A meta-analysis of randomized controlled trials. Journal of Clinical Nursing, 24(23-24), 3425-3440. doi:10.1111/jocn.12976

Dassel, K., \& Carr, D. (2016). Does dementia caregiving accelerate frailty? Findings from the health and retirement study. Gerontologist, 56(3), 444-450. doi:10.1093/geront/gnu078

Dayanim, S. (2009). The acute effects of a specialized movement program on the verbal abilities of patients with late-stage dementia. Alzheimer's Care Today, 10(2), 93-98. doi 10.1097/ACQ.0b013e3181a410ab

Dugeon, S. (2010). Rising tide: The impact of dementia on Canadian society: A study. Toronto, ON: Alzheimer Society of Canada.

Harris, P., \& Caporella, C. (2014). An intergenerational choir formed to lessen Alzheimer's disease stigma in college students and decrease the social isolation of people with Alzheimer's disease and their family members: A pilot study. American Journal of Alzheimer's Disease and Other Dementias, 29(3), 270-281. doi:10.1177/1533317513517044

Hulme, C., Wright, J., Crocker, T., Oluboyede, Y., \& House, A. (2010). Non-pharmacological approaches for dementia that informal carers might try or access: A systematic review. International Journal of Geriatric Psychiatry, 25(7), 756-763. doi:10.1002/gps.2429

Maratos, A., Gold, C., Wang, X., \& Crawford, M. (2008). Music therapy for depression. Cochrane Database of Systematic Reviews, (1), CD004517. doi:10.1002/14651858.CD004517.pub2

Matthews, S. (2015). Dementia and the power of music therapy. Bioethics, 29(8), 573-579. doi:10.1111/bioe. 12148 
Sampath, P., Forbes, D. A., Barton, S., \& Blake, C. (2015). A systematic review of the effectiveness of interventions for persons living with dementia based in the home or community. Perspectives, $38(2), 6$.

Strauss, A., \& Corbin, J. (1990). Basics of qualitative research: Grounded theory procedures and techniques. Thousand Oaks, CA: Sage Publications.

Unadkat, S., Camic, P. M., \& Vella-Burrows, T. (2016). Understanding the experience of group singing for couples where one partner has a diagnosis of dementia. The Gerontologist, gnv698. doi:10.1093/geront/gnv698

Wall, M., \& Duffy, A. (2010). The effects of music therapy for older people with dementia. British Journal of Nursing, 19(2), 108-113. doi:10.12968/bjon.2010.19.2.462 